\title{
SEGURITIES REGULATION: SEGTION 16 (b) APPLIED TO ONE OF TWO POSSIBLE PURCHASE DATES WHICH ENABLES RECOVERY OF SHORT-SWING PROFITS
}

\begin{abstract}
$A_{N \text { INSIDER" }}$ is not liable for "short-swing" profits under Section 16 (b) of the Securities Exchange Act ${ }^{2}$ unless, among other things, there has been a "purchase" of securities as required by that section. In Booth v. Varian Associates, ${ }^{3}$ the First Circuit Court of Appeals considered the problem of defining the term "purchase" in a transaction where an executory contract left certain variables to be determined at a future closing date. The court held that where two possible purchase dates exist, the one which more effectively deters the abuses intended to be eliminated by section $16(\mathrm{~b})$ will be selected.

In Booth, defendant-insiders and the plaintiff-corporation entered into an amended stock purchase contract on February 26, I959, containing a provision that the price per share and number of shares to be received by the insiders would be determined at the contract closing date in accordance with a fixed formula. ${ }^{4}$ The stock was transferred three years later on the closing date, ${ }^{5}$ and within six
\end{abstract}

\footnotetext{
I Directors, officers, and beneficial owners of $10 \%$ of any class of equity security of the issuer are termed insiders for purposes of $\S 16$ by the courts and commentators as a shorthand term of art. Securities Exchance Act of $1934 \S 16$ (a)-(c), 48 Stat. 896,15 U.S.C. $\S 78 \mathrm{p}(\mathrm{a})$ - (c) (1958).

2 "For the purpose of preventing the unfair use of information which may have been obtained by such beneficial owner, director, or officer by reason of his relation. ship to the issuer, any profit realized by him from any purchase and sale . . . of any equity security of such issuer ... within any period of less than six months, ... shall inure to and be recoverable by the issuer, irrespective of any intention on the part of such beneficial owner, director, or officer in entering into such transaction of holding the security purchased or of not repurchasing the security sold for a period exceeding six months. ..." Securities Exchange ACT of 1934 § 16(b), 48 Stat. 896, 15 U.S.C. $\$ 78 \mathrm{p}$ (b) (1958).

s 334 F.2d 1 (Ist Cir. 1964).

- The contract was executed pursuant to an acquisition of Bomac Laboratories, Inc. by plaintiff-corporation. Shortly before execution, defendants assumed positions on the board of directors of plaintiff-corporation; by the terms of the contract, defendants were to deliver a specified number of Bomac shares to plaintiff on the contract closing date, originally specified as July 2, 1962, and subject to acceleration. In return, they were to receive that number of shares of the plaintiff's stock which would have a market value equal to two million dollars on the day prior to the closing date, plus $20 \%$ of the increase in retained earnings realized on the Bomac stock during the period December 31, 1958, to the end of that month preceding the closing date. Id. at 2 .
}

By the terms of the contract, plaintiff-corporation was given the right to ac- 
months thereafter a portion of the stock acquired was sold by the defendants. The corporation sued under section $16(\mathrm{~b})$ to recover profits realized from the sale, and the district court ordered summary judgment for the plaintiff. ${ }^{6}$ The order was affirmed on appeal, with the First Circuit holding that the "purchase" occurred on the closing date rather than the contract execution date. The court reasoned that where two possible purchase dates exist, the one more likely to result in a violation of $16(\mathrm{~b})$ will be chosen. Since the statute of limitations would preclude recovery for sales within six months of the execution date, the closing date was denominated as the purchase. ${ }^{7}$

Prior to the enactment of section $16(\mathrm{~b})$, an insider was often able to use inside information to realize "short-swing" profits at the expense of the public investor. ${ }^{8}$ In 1934, Congress felt elimination of this practice was necessary to restore investor confidence in the securities market by satisfying demands for fair market dealing. Therefore, it adopted an arbitrary six month period within which any profits acquired by an insider on a purchase and sale of his corporation's equity securities may be recovered by the issuer. ${ }^{9}$

celerate the closing date of the contract at will any time prior to July 2, 1962, the specified closing date. On the other hand, defendant-insiders were permitted to accelerate only on their death or legal incompetency (in which event their legal representatives were required to exchange the stock) or on an involuntary change in their positions as directors of either Bomac or the plaintiff. In fact, plaintiff did accelerate the closing date of June 29, 1962. Brief for Appellant, pp. 3-5.

- Varian Associates, Inc. v. Booth, 224 F. Supp. 225 (D. Mass. 1963).

${ }^{7} 334$ F.2d at 4-5. It was also argued by defendants that even if the closing date were denominated as the purchase date, the transaction falls within the provision of $\S 16(\mathrm{~b})$ exempting stock acquired in good faith in connection with a debt previously contracted. Brief for Appellant, pp. 42-48. The court rejected this argument by stating that the debt must exist separately from the stock transaction. The court reasoned that to allow the $\S 16(\mathrm{~b})$ exemption to apply in this case would permit evasion of the act since any acquisition of stock could take the form of a contract in which the seller would owe a debt (obligation to deliver the stock) and the buyer would also assume a debt (obligation to pay for the stock). $t d$. at 5-6; see 1962 DuKE L.J. 589 .

${ }^{8}$ This would happen in transactions between the insider and an investor from the general public who relies only on market place information. For example, suppose an insider discovers that his corporation will probably receive an important government contract, and therefore promptly purchases stock of his corporation. After a sharp rise in market value occasioned by the announcement of the contract, he sells the stock at a profit. The insider has thereby made a profit not by reacting to market place information, but by taking advantage of inside information not equally available to all investors. Congress reasoned that to take profits at the expense of one who is not in a position to acquire such knowledge is a breach of the insider's fiduciary duty. See S. REP. No. 792, 73d Cong., 2d Sess. 9, 20-21 (1934); S. REP. No. 1455, 73d Cong., 2d Sess. 55-68 (1934).

- Congressional investigation disclosed that most of the abuses of insider privileges 
Since the act is remedial rather than punitive, it has no application unless profits are realized by the insider. ${ }^{10}$ Moreover, in certain situations courts have held $16(\mathrm{~b})$ inapplicable for policy reasons even though a purchase has occurred within six months of a sale.11 Where the securities involved were privately held and had no established market, 16 (b) was not applied.12 Here it was reasoned that no disparity of knowledge exists between the insider and the public investor where the market value of the unseasoned security is not readily determinable. Nor has the section been applied where the insider is forced to make the purchase or sale; in these cases recovery has been denied on the theory that control over the transaction was not voluntarily exercised by the insider, and therefore he was not in a position to gain an advantage over the public investor through the misuse of inside information. ${ }^{13}$ The tenor of

occur in short term speculation. Where stock is held for a longer period of time, the market reacts to factors unforeseeable by the insider and the use of inside information becomes less effective. On this basis, Congress enacted the six month period of restraint imposing absolute liability for profits irrespective of the insider's motive or intent. Therefore, the act minimizes the opportunity for abuse without discouraging long term investment and trading by insiders. See H.R. REP. No. 1383, 73d Cong., 2d Sess. 2-5, 24-25 (1934); H.R. REP. No. 1838, 73d Cong., 2d Sess. 16-17, 35-36 (1934); S. REP. No. 792, 73d Cong., 2d Sess. 9, 20-21 (1934).

${ }^{20}$ See Adler v. Klawans, 267 F.2d 840, 846-47 (2d Cir. 1959).

11 The SEC rules have exempted certain transactions from application of $\$ 16(\mathrm{~b})$ which might otherwise fall within the scope of the act. 17 C.F.R. 240.16b-8, 6 \& 7 (exempting certain stock options, long-term options, and acquisitions and dispositions pursuant to mergers or consolidations).

12 Roberts v. Eaton, 212 F.2d 82 (2d Cir.), cert. denied, 348 U.S. 827 (1954); Blau v. Mission Corp., 212 F.2d 77 (2d Cir.), cert. denied, 347 U.S. 1016 (1954).

${ }^{18}$ Ferraiolo v. Newman, 259 F.2d 342 (6th Cir. 1958), cert. denied, 359 U.S. 927 (1959). In this case, the insider responded to a corporate directive to redeem his preferred stock for cash or convert it to common stock. Since the market valuc of the common stock was much higher than the redemption price for the preferred, the insider converted rather than take the loss. The court recognized that from a practical economic standpoint the conversion was involuntary. As an involuntary transaction, 16(b) was not applied. Although this reasoning is not technically in accord with the statutory language which states that any profit is recoverable, it appears that the court read into the statute a legislative intent that no application of $16(\mathrm{~b})$ is required where, by virtue of an involuntary sale, the insider had no opportunity to gain an advantage over other shareholders through the use of inside information. In such a situation, the statutory sanctions will not operate as a curb against short-swing profit-taking.

While the act is not concerned with the insider's motive or intent when entering into the transaction, as Professor Loss points out, "it does seem to be of considerable consequence to consider whether the circumstances were such that the defendant could possibly have obtained an advantage over the public generally which did not already exist." 2 Loss, Securrties Regulation 1069-70 (1961). Cf. Heli-Coil Corp. v. Webster, 222 F. Supp. 831 (D.N.J. 1963), where it was held that since the insider was under no compulsion to convert his corporate debentures, the transaction was 
these qualifications suggest that $16(\mathrm{~b})$ is restricted to those situations where an insider realizes profits in a transaction which affords an opportunity to misuse inside information.

Where these policy qualifications justify the application of $16(\mathrm{~b})$, courts have implemented the statutory prohibition to include a wide variety of transactions. ${ }^{14}$ Situations involving stock conversions, ${ }^{15}$ stock options, ${ }^{16}$ stock warrants, ${ }^{17}$ stock transfers pursuant to corporate reorganization, ${ }^{18}$ and other types of stock disposal and acquisition devices ${ }^{19}$ have been held to be within the scope of section $16(\mathrm{~b})$ sanctions. However, with several exceptions, the courts in these cases have not expressly evaluated policy considerations in choosing between two possible purchase dates; instead, they have relied exclusively on traditional purchase concepts, which frequently has led to confusion. For example, where an insider receives stock warrants, it is necessary to determine whether a purchase occurs at the issuance date or at the date the warrant is exercised. One decision has held that the issuance date is the date of purchase of stock warrants on the theory that the warrant itself is the equity security acquired.20 On the other hand, another case has held that a purchase of stock

voluntary and $16(\mathrm{~b})$ applied. The court did recognize, however, that an involuntary transaction may result in a finding that $16(\mathrm{~b})$ is not applicable.

Both Ferraiolo and Heli-Coil distinguished Park \& Tilford, Inc. v. Schulte, 160 F.2d 984 (2d Cir. 1947), on the ground that although the insider there was forced to convert under threat of redemption at a lower price per share, the insider retained sufficient control over the corporation so that he inight have vetoed a redemption attempt. Under this situation, the insider's transaction can realistically be termed voluntary because he could have avoided placing himself in a forcing situation. The Park of Tilford decision, if taken literally, requires a finding of 16 (b) application whenever a conversion occurs. For this reason, the holding has been criticized as not considering the involuntary transaction situation. See 2 Loss, Securities RegulaTroN 1068 (196I).

14 See generally 2 Loss, Securrties Reculation 1040-192 (1961); Cook. \& Feldman, Insider Trading Under The Securities Exchange Act, 66 HARv. L. REv. 612 (1953); Rubin \& Feldman, Statutory Inhibitions Upon Unfair Use of Corporate Information By Insiders, 95 U. PA. L. Rev. 468 (1947); Comment, 65 Harv. L. Rev. 997 (1952); Comment, 69 Yale L.J. 868 (1960); Comment, 59 Yale L.J. 510 (1950).

15 Park \& Tilford, Inc. v. Schulte, 160 F.2d 984 (2d Cir.), cert. denied, 332 U.S. 761 (1947); Heh-Coil Corp. v. Webster, 222 F. Supp. 831 (D.N.J. 1963).

${ }^{16}$ Blau v. Allen, 163 F. Supp. 702 (S.D.N.Y. 1958).

${ }^{27}$ Truncale v. Blumberg, 80 F. Supp. 387 (S.D.N.Y. 1948) (dictum).

${ }^{18}$ Stella v. Graham-Paige Motors Corp., 192 F. Supp. 100 (S.D.N.Y. 1955), remanded on other grounds, 232 F.2d 299 (2d Cir. 1956), cert. denied, 352 U.S. 831 (1956); Blau v. Hodgkinson, 100 F. Supp. 361 (S.D.N.Y. 1951).

${ }^{10}$ Smolowe v. Delendo Corp., 136 F.2d 231 (2d Cir.), cert. denied, 320 U.S. 751 (1949).

${ }^{20}$ Truncale v. Blumberg, 80 F. Supp. 387, 392 (S.D.N.Y. 1948) (dictum). 
warrants will not occur until the date of election because the issuance is merely an offer to sell by the corporation. ${ }^{21}$

This confusion is not diminished by the statutory definition of purchase as "any contract to buy, purchase, or otherwise acquire."22 Because of the variety of transactions to which the act applies, a workable definition of the purchase requirement has been difficult to formulate. Nevertheless, several traditional purchase tests have been devised by the courts in attempts to apply section $16(\mathrm{~b})$ : a purchase has been held not to occur until the rights and obligations of the insider become irrevocably fixed under the transaction; ${ }^{23}$ where the insider's percentage of ownership does not increase as a result of the transaction, some courts are less favorably disposed to finding a purchase; ${ }^{24}$ but where an insider acquires equity securities of a different class having a higher market value, other courts have held a purchase occurs without regard to the percentage of ownership test. 25

The First Circuit in Booth, however, rejected the precedential value of early $16(\mathrm{~b})$ cases because they involve "problems peculiar to their own types of transactions."26 In so doing, the court

${ }^{31}$ Shaw v. Dreyfus, 172 F.2d 140 (2d Cir.), cert. denied, 337 U.S. 907 (1949). The court reasoned that the issuance of a warrant was not a purchase because it was analogous to a distribution of stock dividends. Therefore, since the defendant had sold warrants instead of exercising his privilege to convert them to stock, 16 (b) was not applied because the sale was not preceded by a purchase within the statutory period. The result of the Shaw decision has been criticized as permitting evasion of the act, because it allows the insider to dispose of stock rights profitably within six months after acquisition and yet not be penalized for using inside information. Sce 2 Loss, Securities Regulation 1077 (1961); Comment, 65 Harv. L. Rev. 997, 1007 (1952). But see Comment, 59 YALE L.J. 510, 521 (1950), noting that control of the issuance by the insider may be determinative of his liability.

22 Securities Exchange Act of 1934, § 3 (a) (13), 48 Stat. 884,15 U.S.C. $\$ 78 \mathrm{c}$ (a) (13) (1958).

2a Blau v. Ogsbury, 210 F.2d 426 (2d Cir. 1954). "It matters not to the speculator who has title or possession or who can vote the stock or receive dividends. What he needs is firm assurance that a fixed quantity can be acquired or disposed of at a fixed price; and his commitments are on that basis." Id. at 427; see Stella v. Graham-Paige Motors Corp., 132 F. Supp. 100 (S.D.N.Y. 1955), remanded on other grounds, 232 F.2d 299 (2d Cir.), cert. denied, 352 U.S. 831 (1956), holding that no purchase occurred in a stock transfer pursuant to a corporate reorganization, where rights and obligations did not arise until purchaser obtained a guarantee of credit to finance the transfer. For cases which provide an inarticulated application of this test, see cases cited notes 20-21 supra.

${ }^{2}$ See Ferraiolo v. Newman, 259 F.2d 342, 346 (6th Cir. 1958), cert. denied, 359 U.S. 927 (1959); Roberts v. Eatou, 212 F.2d 82 (2d Cir.), cert. denied, 348 U.S. 827 (1954).

${ }^{25}$ See Park \& Tilford, Inc. v. Schulte, 160 F.2d 984 (2d Cir.), cert. denied, 332 U.S. 761 (1947) (conversion of preferred stock to common stock); Blau v. Hodgkinson, 100 F. Supp. 361 (S.D.N.Y. I951).

so 334 F.2d at 3. 
also refused to evaluate the transaction exclusively in terms of traditional purchase tests. ${ }^{27}$ Instead, it recognized that if a date may be denominated a purchase under one of these tests, policy factors are significant in focusing attention on whether a "purchase" on that date will result in the abuse which the statute seeks to eliminate.28 Thus, this approach first ascertains whether an alleged transaction contains the traditional attributes of purchase, and then determines whether the legislative purpose reflected in 16 (b) warrants application of the statute to the particular transaction. In addition, where more than one plausible purchase date exists, the same approach is adopted with respect to each date, and the two dates are compared to determine which is most likely to perpetrate abuses susceptible to recovery under the act. ${ }^{29}$

Choice of the closing date in Booth as a purchase appears correct under this analysis. Traditional attributes of a purchase were present at the closing date: ${ }^{30}$ rights and obligations of the insiders under the contract did not become fixed until the price per share and number of shares to be traded were determinable; ${ }^{31}$ moreover, physical acquisition and control over the stock did not occur until the closing date. Assuming, therefore, that the closing date can be

\footnotetext{
${ }^{27}$ For cases dealing with the traditional purchase inquiry see, e.g., Blau v. Ogsbury, 210 F.2d 426 (2d Cir. 1954) (stock option); Stella v. Graham-Paige Motors Corp., 132 F. Supp. 100 (S.D.N.Y. 1955), remanded on other grounds, 232 F.2d 299 (2d Cir.), cert. denied, 352 U.S. 831 (1956) (stock transfer pursuant to corporate reorganization).

An attempt by the courts to consider only the narrow issue of when a purchase occurs in determining the insider's liability tends to result in artificial distinctions between cases. For example, the test which defines the purchase date as that time when the rights and obligations of the insider become irrevocably fixed is undesirable when considered alone. To comply with such a test, the insider must define the elusive concepts of rights and obligations as well as make a difficult determination as to when these elusive factors become relatively certain. For example, the selection of a purchase date in Blau v. Ogsbury, supra, was based solely ou an analysis of rights and obligations without regard to which dates would afford a practical opportunity for misuse of inside information.

${ }^{28}$ Accord, Ferraiolo v. Newman, 259 F.2d 342, 344-45 (6th Cir. 1958), cert. denied, 359 U.S. 927 (1959); Heli-Coil Corp. v. Webster, 222 F. Supp. 831, 835 (D.N.J. 1963). See generally 2 Loss, Securities Regulation 1069-70 (1961).

20334 F.2d at 5 .

${ }^{80}$ See note 23 supra.

:1 The fixed rights and obligations test appears more applicable to the situation presented in the Booth case than does an inquiry into whether the transaction resulted in an increase in defendants' percentage of ownership in the corporation. As a result of the transaction, the defendants' ownership in the corporation increased, but the question of when this increase occurred remains unanswered. The fixed rights and obligations test permits the court to determine when the increase occurred by ascertaining when the insiders' rights and obligations becane sufficiently fixed to result in a purchase.
} 
denominated a purchase, the policy of the act warrants application of $16(\mathrm{~b})$ to such an acquisition of securities. Since the defendants were voluntarily able to select a date of sale within six months of the closing date,,$^{32}$ and were able to deal with securities which were well seasoned and publicly held, ${ }^{33}$ it appears that they could have enjoyed an advantage over the public investor through the use of inside information.

It should be noted, however, that there also were factors in Booth which militate for the choice of the contract execution date. The most persuasive of these is the statute itself, which defines purchase as "any contract to ... acquire."34 Other traditional attributes of a purchase were clearly present: both the insiders and the corporation were firmly committed to transfer stock in accordance with a fixed formula established at the execution date; moreover, the insiders' percentage of ownership increased at that date ${ }^{35}$ because they were assured of at least two million dollars of equity securities in the corporation. Assuming that a sale might occur within six months of the execution date, the policy of the statute would also support application of $16(\mathrm{~b})$ since the insiders might

\footnotetext{
${ }^{82}$ See Heli-Coil Corp. v. Webster, 222 F. Supp. $831^{*}$ (D.N.J. 1963).

Section 16(b) applies to any six month period where a purchase is preceded or followed by a sale. It has been held that where the second of the two tranaactions is involuntary, 16 (b) will not apply. Id. at 835. On the other hand, in Ferraiolo v. Newman, 259 F.2d 342 (6th Cir. 1958), cert. denied, 359 U.S. 927 (1959), it was held that $16(\mathrm{~b})$ did not apply where the first transaction is involuntary. Thus, it might be argued in Booth that since plaintiff enjoyed exclusive control over the determina. tion of the closing date through the use of its acceleration privilege (see note 5 supra), the first transaction was involuntary and, therefore, the act should not apply. Assuming arguendo that the purchase was involuntary, this approach nevertheless seems to overlook the fact that profit taking is dependent upon a voluntary act of the insiders in selecting the subsequent date of sale. Ferraiolo, therefore, seems inconsistent with the basic philosophy of 16 (b).

Furthermore, it might be argued that if the second transaction is involuntary, the act should still apply if there exists an opportunity for taking profits by the use of inside information. For example, if the defendants sold their rights under the contract within six months prior to an involuntarily fixed closing date, which was announced prior to defendants' decision to sell, their knowledge of inside information may have enabled them to predict a market decrease prior to the announced closing date.

ss Plaintiff's stock was listed on the New York Stock Exchange since late 1959. 334 F.2d at 3. For cases which hold $16(\mathrm{~b})$ to be inapplicable where the security involved neither is well seasoned nor has an established market, see note 12 supra.

s. See statute cited note 22 supra.

${ }^{85}$ For cases applying the increase in percentage of ownership test, see note 24 supra.
} 
have obtained an advantage over the public investor through the use of inside information. ${ }^{36}$

Comparison of the two plausible purchase dates, however, compels the conclusion that as a practical matter, choice of the later date would better effectuate the prevention of short-swing profits. Since the formula in the executory contract contained certain variables, the existence and amount of profits on any sale were not determinable until the value per share was ascertained at the closing date. Accordingly, the First Circuit reasoned that a "sale" within six months of the execution date could not result in an enforceable violation of the statute because profits, an essential element of recovery, could not have been determined until after the two year statute of limitations expired. ${ }^{37}$ Furthermore, where the price per share and number of shares to be traded remains uncertain, it would seem impossible for the insider to speculate with the stock during a period prior to the six months before the closing date. ${ }^{38}$ As a practi-

${ }^{30}$ For example, defendants might have been able to voluntarily assign a portion of their rights under the contract within six months after the execution date. They were assured of receiving at least two million dollars worth of securities under the executory contract. See note 4 supra.

However, it is not clear from the facts of the case whether the securities were seasoned at this time. The reported case merely states that the plaintiff's stock had been listed on the New York Stock Exchange since late 1959. It would seem that if no established market existed at the execution date or within six months thereafter, no disparity of knowledge would exist between the insiders and the public investor and, therefore, no policy requirement for application of 16 (b) would exist.

37 The statute of limitations provision of the act states that "no ... suit shall be brought more than two years after such profit was realized." The Booth court assumed that the statute would start to run at any sale date which occurred within six months of the execution date. While this is the normal assumption because profits are nsually determined and actually acquired at a sale date, Booth arguably is a case where the assumption would not apply. Whether profits will be realized from a 1959 sale is pure speculation until the price per share is determined at the closing date. Since ascertainment of any profits is postponed until this date, the realization of profits required to start the limitations period running would not occur until the closing date. It is arguable, therefore, that an enforceable violation would result if either the execution date or the closing date were denominated as a purchase.

The Booth court apparently rejected the defendants' argument that if the statute began running at the 1959 sale, plaintiff could bring the action within the two year limitation period, ask the court to determine if there had been a 16 (b) violation, and if it so determined, further request that judgment be postponed until profits, if any, could be determined. Brief for Appellant, p. 27.

${ }^{38}$ Indeed, the motive for speculation was nonexistent as the defendants were insulated from market fluctuation prior to the closing date. The aggregate value of securities to be received on that date was fixed by factors unrelated to the market. See note 4 supra. Accordingly, the defendants could not sustain a loss on a sale at market price if they waited until the closing date to sell.

Disposal of these shares at any time prior to acquisition at the closing date 
cal matter, therefore, the opportunity for misuse of inside information would not be worth pursuing until the closing date.30 Thus, the Booth court recognized that since the policy of $16(\mathrm{~b})$ is to deter potential abuses, that date which presents the greatest likelihood for abuse is the preferrable choice for the date of purchase. ${ }^{40}$

By looking to policy considerations, Booth reflects a recent trend deviating from the confusion of prior decisions which relied exclusively on traditional concepts of purchase ascertainment. At the same time it permits consistent application of the act and thereby renders less forceful the argument that $16(\mathrm{~b})$ is a trap for the unwary.41

Nevertheless, the Booth assumption that only one of two plausible purchase dates may be selected ${ }^{42}$ falls short of the desired statutory policy of eliminating any short-swing profit resulting from the

might be denominated a short sale prohibited by $\$ 16(c)(1)$. SEcuruties Exchange AcT of 1934, $\$ 16$ (c) (1), 48 Stat. 897,15 U.S.C. $\$ 78 \mathrm{p}(c)(1)$ (1958). Therefore, it is possible that the insiders would be precluded as a matter of law from speculating with this stock before the closing date. This would constitute a cogent reason for a court to postpone the purchase date to the closing date.

${ }^{80}$ Defendants did not report their acquisitions under $\$ 16$ (a) of the act until Junc 1962. Brief for Appellant, p. 28, n.6. This adds weight to the contention that the transaction was not a "purchase" until that time.

Conceivably, the defendants could have sold their rights to the stock immediately prior to the closing date with the ability to reasonably predict the closing price per share. Market fluctuation, however, would detract from this ability as such a salc moved away in time from the closing date. Thus, a sale more than six months prior to the closing date would be extremely speculative and, as a practical matter, the usc of inside information on the sale date would be of little consequence.

${ }^{\circ}$ See Ferraiolo v. Newman, 259 F.2d 342 (6th Gir. 1958), cert denicd, 359 U.S. 927 (1959), where the court stated, "Every transaction which can reasonably be de. fined as a purchase will be so defined, if the transaction is of a kind which can possibly lend itself to the speculation encompassed by Section 16(b)." 259 F.2d at 343 .

11 For a discussion of criticisms of $\S 16(\mathrm{~b})$, see 2 Loss, Securities Regulation 1087. 90 (1961).

$\$ 2$ The courts have apparently never expressly held that more than one purchasc date may be possible in a single transaction, but such a result may be implied from the language of several cases. Smolowe v. Delendo Corp., 136 F.2d 231, 239 (2d Cir.), cert. denied, 320 U.S. 751 (1943); Truncale v. Blumberg, 80 F. Supp. 387, 390-91 (S.D.N.Y. 1948); see 2 Loss, Securities Regulation 1076-79 (1961). Although purchasc traditionally implies that title to an article can pass only once, if the purpose of the statute is "to squeeze all possible profits out of stock transactions, and thus to establish a standard so high as to prevent any conflict between the selfish interest of a fiduciary officer, director or stockholder and the faithful performance of his duty" (Smolowe v. Delendo Corp., supra at 239), the traditional requirements of purchase should be discarded in favor of a more liberal interpretation of the statute. Even if technical purchase concepts are to be controlling, however, it is arguable that at each of several plausible purchase dates, the insider acquires a portion of the rights in the equity security, and a purchase and sale of any portion of thesc rights within a six month period permits application of $16(\mathrm{~b})$ sanctions. 
abuse of inside information. The statute does not limit the court to a choice of only one purchase date in any transaction; thus it would seem that any date occurring within six months of a sale which offers the likelihood of potential abuse should be denominated a purchase if it satisfies traditional purchase concepts. Anything less offers opportunity for evasion of the act. For example, if the insiders in Booth could have sold a portion of their rights to the securities within six months after executing the contract, and sold the remainder of the acquired stock within six months of the closing date, under a literal reading of Booth only one of the two dates could be denominated a purchase. This would allow profits realized on a sale within six months of the other date to be retained by the insider in contravention of the statute's policy. To denominate both dates as purchase dates, thereby allowing recovery of profits realized from a sale within six months of either date, would effectuate the statutory policy of eliminating all potential abuses. 